Ethiopian Journal of Environmental Studies \& Management 9(5): 593 - 603, 2016.

ISSN:1998-0507

Submitted: April 20, 2016

doi: http://dx.doi.org/10.4314/ejesm.v9i5.6

\title{
PROFESSIONALS VIEW ON THE CAUSES AND EFFECTS OF CONSTRUCTION PROJECTS ABANDONMENT IN IBADAN METROPOLIS, NIGERIA
}

*TIJANI, M.A. AND AJAGBE, W.0.

Department of Civil Engineering, University Of Ibadan, Ibadan, Oyo State, Nigeria

\begin{abstract}
This descriptive study aimed to conduct an investigation on the causes and effects of abandonment of construction projects in Ibadan metropolis Nigeria, and then suggest the way forward. A structured questionnaire with Likert Scale design approach was administered on 70 consultants (Architects, Engineers, Quantity Surveyors and Builders) obtained from regulatory bodies of each profession. 49 responses were obtained to give a return rate of $70 \%$. Analysis of data was done by a statistical formula to calculate the relative importance index (R.I.I). The higher the R.I.I value, the more important is the cause or effect. 23 important causes of Abandonment of construction projects were identified, which include: lack of adequate fund allocation, payment remittance delay, death of the investor/client/owner, improper project planning and design etc. Then 10 main effects of construction projects abandonment were established, which include: loss of strength of structural members, visual defect to surrounding/project site, hidden places for dangerous animals, pollution, marginalization of population etc. It was concluded that if the incessant causes are seriously dealt with through the implementation of various measures opined to each cause in the study; projects abandonment will be a thing of the past in the study area and the nation in general.
\end{abstract}

Key Words: Abandonment, Construction Projects, Ibadan, Causes and Effects

\section{Introduction}

The fast modernization of living city life has paved way to the increased demand of construction industry. In Ibadan, more buildings are constructed in order to provide space for the growing population of people and industries. Nowadays, there are already numerous abandoned construction projects within the area. Within the municipality of Ibadan alone, several abandoned buildings and roads can be sighted. According to Tomas (2013), the most striking indication of neighborhood decline is abandonment of property.

In many countries, development process in construction industry plays an important role. It is both growth-initiating and growth dependent, (Fadhlin, 2004).The industry establishes buildings and infrastructure works required for socio-economic growth. The success of economic development will further lead to increase in disposal income, thereby generating demand for additional construction activities. According to

*Corresponding Author: Tijani, M.A.

Email: murikilekun@gmail.com 
UKCG (2009) "The construction industry is a driver of growth in other sectors due to its heavy reliance on an extended and varied supply chain". All other sectors of the economy like manufacturing, education, health, sports etc, depend on construction industry for performance.

Nwachukwu et al. (2010) described project abandonment as the refusal or failure, to complete a contract before a practical completion dates. The unceasing abandonment of construction projects is so shocking in the developing countries such that Nigerian has remained one of the countries in such difficulty (Ayodele and Alabi, 2011; Kotangora, 1993; Osemenan, 1987). According to News Agency of Nigeria (NANS 2011), the Secretary General of The National Union of Civil Engineering, Construction, Furniture and Wood Workers said "in the past two years, 40,000 members of the union have been thrown into the labour market because of abandoned projects.

El-Rufai (2012) attributed the reasons for project abandonment to poor planning, haphazard procurement practices, incompetent project management, lack of coherence and consistency with other programmes and pervasive lack of continuation in policies as occupiers of political offices change. Akindoyeni (1989) qualitatively reasoned that some of the causes of project abandonment in Nigeria are: deaths of client, inability of client to attract funds and lack of planning. Like other developing countries, such as Saudi Arabia (Assaf et al., 1995) and Libya (Saleh, 2009), Nigerian construction industry has suffered many setbacks in terms of completion of projects at stipulated period within the predetermined sum. Majority of the construction projects in Nigeria experience time and cost overrun which in turn lead to the abandonment of projects.

Oyo State Government has embarked on one type of project or the other especially in its state capital (the study area) to make life more meaningful for her people but many of these projects were not well conceived and completed. The private sectors have also failed to complete many projects as scheduled and put into proper use. Therefore, it is imperative to identify the reasons behind this. The objective of this study is to investigate the causes and effects of construction projects being abandoned and suggest workable solution to forestall the problems of abandonment of construction projects in Ibadan metropolis.

\section{Methodology}

A structured close ended questionnaire was designed to capture data on the causes and effects of abandonment of construction projects in Ibadan metropolis. Seventy copies of a questionnaire were administered on consultants (Architects, Engineers, Quantity Surveyors and Builders) based in the study area. The questionnaire was divided into general information of respondents, causes, and effects of abandonment of construction projects in Ibadan metropolis.

A list of Ibadan-based registered consultants was obtained from professional Registration Boards like Architect Registration Council of Nigeria (ARCON), Council for Regulation of Engineering (COREN), Council of Registered Builders of Nigeria (CORBON) and Quantity Surveyors 
Registration Board of Nigeria (QSRBN). The questionnaire was developed using the five (5) point Likert scale method (5 = Strongly Agreed (SA); 4 = Agreed (A); 3 = Unsure (US); 2 = Disagreed (DA); and $1=$ Strongly Disagreed (DSA).

The data was analyzed utilizing the frequency table and Relative Importance Index (R.I.I) approach that was advocated for and used by Lim and Alum (1995) in their work. This is given as:

R.I.I $\left.=\left(5 n_{5}+4 n_{4}+3 n_{3}+2 n_{2}+n_{1}\right) / 5 N\right)$

Where: $\mathrm{n}_{5}=$ Strongly Agree $(\mathrm{SA}) ; \mathrm{n}_{4}=$ Agree (A); $\mathrm{n}_{3}=$ Unsure (US); $\mathrm{n}_{2}=$ Disagree (DA); $\mathrm{n}_{1}=$ Strongly Disagree (SDA); and $\mathrm{N}=$ number of respondents.

\section{Results and Discussion}

Table 1 shows the analysis of questionnaire administered and collected. The total number of questionnaire sent out were 70 copies out of which 49 responses were obtained to give a return rate of $70 \%$. This response rate was acceptable in a study with such a total questionnaire sample size (Kobbacy, 2013).

Table 1: Questionnaire distribution analysis

\begin{tabular}{lll}
\hline Description & Total Number & Percentage (\%) \\
\hline Questionnaire sent out & 70 & 100 \\
Questionnaire received & 49 & 70 \\
\hline
\end{tabular}

Tables 2 presented the background information about the respondents. The characteristics include profession, academic qualification, services rendered and work experience. The results revealed that $10.2 \%$ of the respondents were builders, $36.7 \%$ were architects, $34.7 \%$ were engineers and $18.4 \%$ were quantity surveyors. The highest academic qualifications of respondents were HND (20.4\%), BSc.(44.9\%), and MSc. $(34.7 \%) .69 .4 \%$ of the respondents practice consultancy while $30.6 \%$ practice contracting. $38.8 \%$ of the respondents had less than 5years of work experience, $28.6 \%$ had 6 - 10years, $16.3 \%$ had $11-15$ years, $12.2 \%$ had $16-$ 20years and $4.1 \%$ had above 20years of work experience.

Table 3 shows the result of the assessed current condition of certain projects and the benefit of what the project is expected to add to the immediate built environment. The research findings reveal that the question of project exists to bring about the birth of new product had R.I.I value of 0.9347 . The question of project abandonment are predominant in our society today had a R.I.I value of 0.9224 . While the question of some projects is successfully implemented, completed and commissioned while most are abandoned mid-way was apparently unlike the other as it had a R.I.I Value of 0.8980 .

Thus the research findings confirm that construction projects are delivered to the society to bring about new products and services which is in consonance with the opinion of Franks (2006) that projects are developed to create a unique products and service in the built environment. The study also affirms that most projects are abandoned in Nigeria and with fewer of the projects successfully completed. This is in agreement with the argument of Ayodele and Alabi, (2011), Kotangora, (1993), and Osemenan, (1987), as presented in their works and reports. 
Table 2: Background information about the respondents

\begin{tabular}{lll}
\hline & Frequency & Percentage $(\%)$ \\
\hline Profession of respondents & 5 & 10.2 \\
Building & 18 & 36.7 \\
Architecture & 17 & 34.7 \\
Engineering & 9 & 18.4 \\
Quantity Surveying & 49 & 100 \\
Total & & \\
Highest academic qualification & 10 & 20.4 \\
HND & 22 & 44.9 \\
BSc. & 17 & 34.7 \\
MSc. & 49 & 100 \\
Total & & \\
Services rendered by the Organizations & 34 & 69.4 \\
Consultancy & 15 & 30.6 \\
Contracting & 49 & 100 \\
Total & & \\
Work experience of respondents & 19 & 38.8 \\
Less than 5yrs & 14 & 28.6 \\
6-10yrs & 8 & 16.3 \\
$11-15 y r s$ & 6 & 12.2 \\
16-20 & 2 & 4.1 \\
Above 20yrs & 49 & 100 \\
Total & &
\end{tabular}

Table 3: Projects Situation and its Benefit in the Built Environment

\begin{tabular}{llllllll}
\hline Rank & Situation and Benefit & 1 & 2 & 3 & 4 & 5 & R.I.I \\
\hline 1 & $\begin{array}{l}\text { Project exist to bring about the birth of a new } \\
\text { product }\end{array}$ & 0 & 2 & 12 & 35 & 0.9347 \\
2 & $\begin{array}{l}\text { Project abandonment are predominant in our society } \\
\text { today (construction projects) }\end{array}$ & 0 & 4 & 11 & 34 & 0.9224 \\
3 & $\begin{array}{l}\text { Some projects are successfully implemented, } \\
\text { completed and commissioned while most are } \\
\text { abandoned mid-way }\end{array}$ & 2 & 2 & 15 & 30 & 0.8980 \\
\hline
\end{tabular}

Table 4 presented in rank the identified factors responsible for abandonment of construction projects, the findings confirm that at least 23 factors were the causes for which most projects are abandoned. The most important cause as confirmed in the findings is the lack of adequate funds allocation with a R.I.I 0.9551. If projects are expected not to be abandoned, adequate funds allocation to project implementations is very essential. This critical factor is in agreement with ElRufia (2012) who stated that contract awards should be guided by the procurement act which among others stated that funds must be available before contract is awarded. Odenyinka and Yusuf (1997), also confirm this with their contention that the project owners' cash 
flow in the project implementation is a cause to project abandonment. It is also collaborated in the PPAC (2011). Ihuah and Fortune, (2013), Ihuah and Eaton (2013) and NHP (2011) stressed that a major constraint to development projects completion since 1960 to the present state of affair is a lack of funds.

Payment remittance/disbursement delay of money due to the projects contractors is a another significant factor with R.I.I 0.9501 amongst the causes of project abandonment, which agrees with the contention of Ayodele and Alabi (2011) that delays in remittance of payment due for a project to the contractor is a bane and a cause to project abandonment. According to Ewa (2005) contractors do not keep to credit terms with their bankers when contracting organizations refuse to disburse progress payments as at when due and this makes them to incur more interest charges on loans. This is collaborated in the report of PPAC (2011) which stated that 'consistent delays in payment to contractors lead to massive claims for overhead costs, interests and additional costs'.

Another factor responsible for abandonment of construction projects is death of the investor/client/owner with a R.I.I 0.9429 which is in agreement with Ayodele and Alabi (2011) work on causes of construction project abandonment in Nigeria. Similarly, the result of the study with a R.I.I. 0.9347 shows that improper project planning and design is another identified cause of project abandonment and this agrees with Ewa (2005) who stated that planning without facts is planning to fail. This is also in agreement with Ayodele et al. (2011), El-Rufai (2012), PPAC (2011),
Adedeji (1998), Essenwa (2004), and Opara (1986).

Leadership instability with a R.I.I 0.9306 is another factor of abandonment of project in agreement with Omoniyi (1996) and Onikute (1988) who opined that changes in government/administration have often meant changes in policies. At these times, project commenced by previous political administrative are often abandoned to give way for their newly concerned idea.

Inconsistencies in government policies and change of investment purpose with R.I.I 0.9306 and 0.9184 respectively create lack of coherence and consistency in project management and execution. This is in agreement with ElRufia (2012), Akuta (2009) and Ewa (2005) who opined that pervasive lack of continuation in policies as occupiers of political offices change creates the emergence of abandoned projects.

Another root cause of project abandonment identified in the study is improper project estimate with a R.I.I. 0.9225 . Many projects are attributed with poor costing as the costing is done outside the locality where the project is to be located without consideration of the environment. This is in agreement with Ayodele et al. (2011), PPAC (2011) and Ewa (2005).

Incompetent project manager is another cause of project abandonment identified with a R.I.I. 0.9020. Competent personnel should be provided for the implementation of the project to avoid abandonment. This is in agreement with the opinion of PPAC (2011) report, Ayodele et al. (2011) and Ewa (2005). Other cause of project abandonment identified is unjustified project aim or not meet with a R.I.I 0.8980. Projects are 
conceived based on extraneous pecuniary reasons. This is in agreement with ElRufai (2012) and PPAC (2011) who were of the opinion that well defined vision and objective precedes execution phase if the project is not to be abandoned along the way. Another serious factor causing project abandonment in Nigeria as indicated by the study is the incessant community interferences in project development and management which is stressed in Ihuah and Benebo (2014) work. Lack of Project Risk Assessment is another important cause which is in agreement with Chan et al. (2002) who argued that the project abandonment result from a lack of understanding of risk and liability assessments.

Similarly, the result of the study with R.I.I 0.7876 shows that lack of project mission/task communication, is another cause delay which usually leads to project abandonment, this finding agreed with what was found by Frimpong et al., (2003). Land or legal disputes is also a cause of abandonment which is in consonance with Ihuah and Benebo (2014) who stressed that land or legal disputes is so much pronounced that even most of the disputes take ages to be attended to in the court before providing judgment on such disputes, and because legal dispute exist, no project implementation shall continue or even commence unless such dispute is/are completely resolved.

Improper/Poor Documentation of Contract Agreement/conditions (R.I.I 0.6857 ) is another factor surveyed in the study which is seen as a critical factor for project abandonment. This agrees with Gana and Olorunfemi (2015) who stressed that poor documentation or circumvention of contract conditions will precipitate confusion and ultimately lead to project failure.

The remaining causes of project abandonment such as: climatic condition, increasing material costs and sometimes lacking, unplanned urbanization system, lack of stakeholder involvement, improper project budgeting, lack of need assessment and bureaucratic bottlenecks, are also confirmed in this study as the causes of project abandonment. These are also supported by the works of Ihuah and Fortune (2013), Ihuah and Eaton (2013), Ayodele and Alabi (2011), Aluko (2008), and Abdul Kadir, et al. (2005), who in their study stressed that the abandonment of projects are associated with all of or any of these factors/causes. For instance, a lack of stakeholders' participation in project implementation can detract the achievement of the project mission and at the short run causes the construction project to be abandoned. Also, it is normal that every project development should have a need assessment before embarking on such project this will justify whether the expected project development is needed in that area before commencing and completing the development, rather than having the project in a void situation at the end. The issue of natural disaster as stressed in this study is in agreement with Ihuah and Benebo (2014).

Table 5 emerged in a proposition to establishing the effects of these causes of construction project abandonment. The findings confirm that ten (10) negative impacts were significance and these are: Leads to loss of strength of structural members (R.I.I 0.9837, ranked 1st); Visual defect to surrounding/project site (R.I.I 0.9755, ranked 2nd); Hidden places for dangerous animals (R.I.I. 0.9714, 
ranked 3rd); Pollution (R.I.I. 0.9633, ranked 4th); Marginalization of population (R.I.I. 0.9633, ranked 5th); It becomes a waste of finance and materials resources (R.I.I. 0.952 ranked 6th); It leads to loss of economic value of the area (R.I.I. 0.9510 ranked 7 th); It deprive government of the expected revenue from property tax (R.I.I. 0.9388 ranked 8th); It leads to increase in unemployment (R.I.I. 0.9347 ranked 9th); It leads to conflict between public administration and private sector (R.I.I. 0.8694 ranked 10th)

The $1^{\text {st }}$ ranked effect as confirmed by the findings is in accordance with the work of Tomas (2013) who stressed that steel corrosion and concrete deterioration are the major factors that affect the stability and integrity of structural members of any abandoned building. Deterioration damage of concrete of any abandoned building usually increases as the years pass by. As the concrete becomes old, the concrete strength decreases and the service life of concrete shortens. Moisture causes corrosion of steel reinforcements and results in decrease of tensile strength of steel reinforcement making it weak.

Table 4: Factors Causing Abandonment of Projects

\begin{tabular}{|c|c|c|c|c|c|c|c|c|}
\hline Rank & Causes for Abandoning Projects & & 1 & 2 & 3 & 4 & 5 & R.I.I \\
\hline 1 & Lack of adequate fund allocation & & 0 & 0 & 0 & 11 & 38 & 0.9551 \\
\hline 2 & Payment Remittance Delay & & 0 & 0 & 0 & 12 & 37 & 0.9501 \\
\hline 3 & Death of the Investor/Client/owner & & 0 & 0 & 0 & 14 & 35 & 0.9429 \\
\hline 4 & Improper Project Planning and Design & & 0 & 0 & 0 & 16 & 33 & 0.9347 \\
\hline 5 & Leadership Instability & & 0 & 0 & 2 & 13 & 34 & 0.9306 \\
\hline 6 & Inconsistence in government policies & & 0 & 0 & 0 & 17 & 32 & 0.9306 \\
\hline 7 & Improper Project Estimates & & 0 & 0 & 0 & 19 & 30 & 0.9225 \\
\hline 8 & Improper Project Budgeting & & 0 & 0 & 4 & 11 & 34 & 0.9224 \\
\hline 9 & Change of Investment Purpose & & 0 & 0 & 0 & 20 & 29 & 0.9184 \\
\hline 10 & Project Manager Incompetence & & 0 & 0 & 0 & 24 & 25 & 0.9020 \\
\hline 11 & Unjustified Project Aim or Not Meet & & 0 & 2 & 2 & 15 & 30 & 0.8980 \\
\hline 12 & Materials Increasing Costs and Lacks & & 0 & 0 & 8 & 11 & 30 & 0.8898 \\
\hline 13 & Community Interference & & 0 & 2 & 2 & 18 & 27 & 0.8857 \\
\hline 14 & Lack of Project Risk Assessment & & 0 & 2 & 3 & 16 & 28 & 0.8857 \\
\hline 15 & Lack of Stakeholders Involvement & & 0 & 1 & 3 & 20 & 25 & 0.8816 \\
\hline 16 & Unplanned Urbanization System & & 0 & 4 & 5 & 20 & 20 & 0.8458 \\
\hline 17 & Lack of Proper Need Assessment & & 0 & 0 & 4 & 25 & 19 & 0.8449 \\
\hline 18 & Project Mission Communication Lacking & & 0 & 8 & 9 & 10 & 22 & 0.7876 \\
\hline 19 & Land or Legal Disputes & & 0 & 7 & 4 & 21 & 15 & 0.7633 \\
\hline 20 & $\begin{array}{l}\text { Improper/Poor Documentation of } \\
\text { Agreement }\end{array}$ & Contract & 4 & 5 & 12 & 22 & 6 & 0.6857 \\
\hline 21 & Bureaucratic Bottleneck & & 4 & 11 & 10 & 16 & 9 & 0.6835 \\
\hline 22 & Climatic Conditions & & 4 & 9 & 15 & 13 & 8 & 0.6490 \\
\hline 23 & Natural Disaster & & 10 & 16 & 3 & 9 & 11 & 0.5796 \\
\hline
\end{tabular}

Effects of construction projects abandonment such as visual defect to surrounding/project site, hidden places for dangerous animals, pollution, 
marginalization of population and loss of economic value of the area as confirmed is this study are supported by Ibrahim (2014) who revealed that the main effects of project abandonment on the immediate environment are unattractive view, bushy surrounding, stealing and robbery cases, adolescent hang out and dating places, mosquito breeding problems, difficult marketability, hiding places for dangerous animals like snakes and insects and risk of sudden collapse of dilapidated walls.

Carrero et al. (2009) also supported some of the findings in this study by grouping negative impacts of abandoned projects into two viz. (i) Visual impacts which include: pollution, erosion, landscape modification, biodiversity decrease and (ii) Socio-Economic impact which include: unemployment increase, conflict between public administration and private sector, Marginalization of population and loss of economic value of the area.

Also, the issue of project abandonment leads to loss of economic value of the area agrees with the assertion of Efenudu (2010) that project abandonment would affect the property values in a locality. Other effects such as of waste of financial and material resources, leads to increase unemployment and the deprivation of government of the expected revenue from property tax have also been acknowledged by Ayodele and Alabi (2011) and Aluko (2008) as the effects of project abandonment.

Table 5: Effects of Abandonment of Projects

\begin{tabular}{|c|c|c|c|c|c|c|c|}
\hline Rank & Effects of Abandoning Projects & 1 & 2 & 3 & 4 & 5 & R.I.I \\
\hline 1 & $\begin{array}{l}\text { Leads to loss of strength of structural members } \\
\text { (Steel corrosion \& concrete deterioration) }\end{array}$ & 0 & 0 & 0 & 4 & 45 & 0.9837 \\
\hline 2 & Visual defect to surrounding/project site & 0 & 0 & 0 & 6 & 43 & 0.9755 \\
\hline 3 & Hidden places for dangerous animals & 0 & 0 & 0 & 7 & 42 & 0.9714 \\
\hline 4 & $\begin{array}{l}\text { Pollution (Abandoned projects usually trigger the } \\
\text { creation of uncontrolled \& unsupervised garbage } \\
\text { disposal) }\end{array}$ & 0 & 0 & 0 & 9 & 40 & 0.9633 \\
\hline 5 & $\begin{array}{l}\text { Marginalization of population (Abandoned projects } \\
\text { are used by homeless people, who live under } \\
\text { unhealthy and dangerous conditions without public } \\
\text { services and with risk of building collapse) }\end{array}$ & 0 & 0 & 2 & 5 & 42 & 0.9633 \\
\hline 6 & $\begin{array}{l}\text { It becomes a waste of finance and materials } \\
\text { resources }\end{array}$ & 0 & 0 & 1 & 8 & 40 & 0.9592 \\
\hline 7 & It leads to loss of economic value of the area & 0 & 0 & 4 & 4 & 41 & 0.9510 \\
\hline 8 & $\begin{array}{l}\text { It deprive government of the expected revenue from } \\
\text { property tax }\end{array}$ & 0 & 0 & 5 & 5 & 39 & 0.9388 \\
\hline 9 & It leads to increase in unemployment & 0 & 0 & 2 & 12 & 35 & 0.9347 \\
\hline 10 & $\begin{array}{l}\text { It leads to conflict between public administration and } \\
\text { private sector }\end{array}$ & 0 & 2 & 5 & 16 & 26 & 0.8694 \\
\hline
\end{tabular}




\section{Conclusion and Recommendation}

The study identified 23 important causes that are responsible for the abandonment of construction projects. Then 10 main effects were demonstrated. The study has also established that projects abandonment is an indication of neighborhood decline and that if the incessant causes are seriously dealt with there will be elimination or reduction of the rate of abandonment in the study area and this shall improve provision of housing for all especially low-income earners, creation of employment opportunity for professionals in the construction industry, reduction of waste of fund, human and materials on the part of the client, as well as, enhanced physical and socio-economic development of the city. Also, if private projects are well completed, there won't be any reduction on the combined values of the properties and the total income receivable from the properties will not be reduced.

It is recommended that adequacy of funds and budgetary allocation should be ensured in compliance with the Public Procurement Act. The governments should sustainably promote the convention of providing adequate policies and the continuity of those policies by any incoming government. Adequate planning for any given project at inception based on detailed design, costing and timelines should be undertaken. Well trained project managers should be used in project supervision. The time and cost estimation of the project should be accurate. All changes should be done before the start of construction and if the construction project has started, it should be completed and the case of abandonment should not be considered. The disputes, negotiations and court cases should be solved on time and it is preferred that they should not happen and if they happen then the timely solution should be done.

\section{References}

Abdul Kadir, M.R., Lee, W.P., Jaafar, M.S., Sapuan, S. M. and Ali, A.A.A. (2005). Factors Affecting Construction Labour Productivity for Malaysian Residential Projects, Structural Survey, 23(1): 42 - 54.

Adedeji, A.O. (1998). Inflation of Production Planning Techniques on the Performance of Construction Firms in Nigeria, Journal of the Federation of Building Contractor in Nigeria, 13(1): 3-24.

Akindoyeni, A. (1989). The Management of Abandoned Project, Journal of Nigerian Institute of Building, 1(2): 27.

Aluko, O.O. (2008). Construction Project Abandonment in Nigeria: A Threat to National Economy; Knowledge Review, 16(3): $18-23$.

Assaf, S.A., Alkhalil, M. and Al-Hazmi, M. (1995). Causes of delay in large building construction projects. $J$. Manage. Eng., ASCE. 11(2): 45-50.

Ayodele, E.O. and Alabi, O.M. (2011). Abandonment of Construction Projects in Nigeria: Causes and Effects; Journal of Emerging Trends in Economics and Management Sciences (JETEMS), 2(2): 142-145.

Carrero, R., Malvárez, G., Navas, F. and Tejada, M. (2009). Negative Consequences on Abandoned Urbanisation Projects in the Spanish Coast and its Regulation in 
the Law. Journal of Coastal Research, SI 56 (Proceedings of the 10th International Coastal Symposium), 1120 - 1124, Lisbon, Portugal, ISBN 0749-0258

Chan, A.P.C., Scott, D. and Lam, E.W.M. (2002). Framework of Success Criteria for Design/Build Projects. Journal of Management in Engineering, 18(3): 12-28.

Efenudu, F.O. (2010). Causes and Effect of Abandonment of Project on Property Value; A Case of Port Harcourt; Unpublished First Degree Dissertation, Department of Estate Management, Faculty of Environmental Sciences, Rivers State University of Science and Technology, Nigeria.

El-Rufai, N.A. (2012). The tragedy of abandoned projects. Nigeria Intel. Retrieved from http://www.nigeriaintel.com

Ewa, U.E. (2005). The Budgetary process and educational developmentEmphasis on how to avoid abandoned projects.Education Tax Fund workshop on financing education in Nigeria.

Essenwa, F.O. Jr (2004). Project Procurement Method in Due Process or How to Execute Capital Project Effectively; Department of Physical Planning and Development, Nigerian Universities Commission Abuja, Nigeria.

Fadhlin, A. (2004). Construction Industry and economic development. The Malaysian scene. Johor. University Technology Malaysia.

Franks, T.R. (2006). Sustaining Projects Benefits: Masters Course Manual. University of Bradford, UK: Centre for International Development
Frimpong, Y., Oluwoye, J., and Crawford, I, (2003). Statistical Methods, 2nd Ed. Academic, New York.

Gana A.J. and Olorunfemi K.O. (2015). Human Elements and factor contribution and consideration in construction Projects towards completion (the Nigeria Experience). International Research Journal of Engineering Science, Technology and Innovation (IRJESTI), 4(1): 12-18.

Ibrahim, T.A. (2013). Causes and Effects of Construction Projects Abandonment in Ilorin Metropolis Scientific Research and Impact, 3(4): 65-74. Available online at http://scienceparkjournals.com/sri

Ihuah, P.W. and Fortune, J.C. (2013). Toward a Framework for the Sustainable Management of Social (Public) Housing Estates in Nigeria. Journal of US-China Public Administration, 10(9): 901-913.

Ihuah, P.W. and Eaton, D. (2013). A Framework for the Sustainable Management of Social (Public) Housing Estates in Nigeria: a pilot study; A Paper Presented at RICS COBRA Research Conference, New Delhi, India (available at www.wrics/cobra.com)

Kobbacy, K. (2013). Introduction to Quantitative Research-Part 2: Estimation, Significant Tests \& Correlations and Decision Models. Available:http://blackboard.salford. ac.uk/bbcswebdav/pid-749238-dtcontent-rid1236192_1/courses/NBPMROAR/ Estimation\%20Significant\%20Tests $\% 20$ Correlation $\% 20$ and $\% 20$ Decisi on\%20Models\%20\%5B2012- 
13\%5D.pdf (accessed on $10 / 04 / 2015)$.

Kotangora, O.O. (1993). Project Abandonment, Nigerian Tribune.

Lim, E.C. and Alum, J. (1995). Construction Productivity: Issues Encountered by Contractors in Singapore; International Journal of Project Management, 13(1): 51-58.

NANS (2011). Construction workers want law to reduce rate of abandoned projects.

Available:http://www.nanngronline. com/section/general/constructionworkers-want-law-to-reduce-rateof-abandoned-projects. Accessed on April 22, 2015.

NHP (2011). National Housing Policy Draft; Federal Government of Nigeria, Abuja.

Nwachukwu, C.C., Echeme, I. and Okoli, M.N. (2010). Project Management Factor Indexes: a Constraint to Project Implementation Success in the Construction Sector of a Developing Economy. European Journal of Scientific Research Vol. 43, No. http://www.eurojournals.com/ejsr.ht $\mathrm{m}$.

Odenyinka, H.A. and Yusuf, A. (1997). The Causes and Effects of Construction Delays on Cost of Housing Project in Nigeria; Journal of Financial Management and Property and Construction, 2: 3141.
Omoniyi, M.I. (1996). A critical analysis of abandonment of projects. Journal of Building Sciences and Management. 11(1): 4-10.

Onikute, A.B. (1988). Effects of contract termination on the cost of building project. Builders Magazine, 5(19), 5-18.

Opara, N. (1986). Construction Management Control and Planning; Journal of Construction Economics, 3: 12-15.

Osemenan, I. (1987). Project Abandonment; New Watch Magazine, 1: 15.

Saleh, A.T. (2009). Causes of Delay in Construction Projects in Libya, The Int. Conference on Economics \&Administration, Faculty of Administration and Business University of Bucharest Romania; ICEA- FAA Buncharest, 14-15 Nov 2009.

Tomas, U.G. (2013). Forensic Investigation of Abandoned GSIS Building in Manila. International Journal of Disaster Recovery and Business Continuity, 4: 23-34.

UKCG (2009). United Kingdom Construction Group http://www.ukcg.org.uk/fileadmin/d ocuments/UKCG/Key_facts/Fact_s heet_Constructionstimulating_econ omy.pdf.Accessed on April 25, 2015. 